\title{
Methanoplanus limicola, a Plate-Shaped Methanogen Representing a Novel Family, the Methanoplanaceae
}

\author{
Gertrud Wildgruber ${ }^{1}$, Michael Thomm ${ }^{1}$, Helmut König ${ }^{1}$, Kurt Ober $^{2}$; Theodoro Ricchiuto ${ }^{3}$, and Karl O. Stetter ' \\ ' Lehrstuhl für Mikrobiologic, Universität Regensburg, D-8400 Regensburg, Federal Republic of Germany \\ ${ }^{2}$ Lehrstuhl für Genetik, Universilät Regensburg, D-8400 Regensburg, Federal Republic of Germany \\ 'A gip S.p.A., 20097 S. Donato Milanese (Milan), Italy
}

\begin{abstract}
Ahstract. An angular plate-shaped weakly motile mesophilic methanogen was isolated from a swamp of drilling waste in llaly. Growth occurs on $\mathrm{H}_{2} / \mathrm{CO}_{2}$ or on formate. Acetate is required in addition. The optimal doubling time is $7 \mathrm{~h}$ at 40 . (C. The cell envelope is composed most likely of glycoprotein subunits in hexagonal arrangement. The GC-content of its DNA is $47.5 \mathrm{~mol} \%$. On the basis of DNA-RNA hybridization it was found to represent a new family, the Methanoplanaceae within the order Methanomicrobiales.
\end{abstract}

Key words: Methanogens - Archaebacteria - Cell division - Glycoprotein - Acctate - Taxonomy

Recently, a square-shaped fat bacterium was discovered in a salluraled salt brine (Walsby 1980; Stoeckenius 1981), which, however, cannot yet be cultivated in the laboratory. It was assumed (Walsby 1980) that the unusual shape may be explained by the absence of cell turgor in bacteria in a high ionic strength environment. From the composition of its envelope, Walsby $(1980)$ speculates that this organism belongs to the archacbacterial.

Here, we report on the isolation and properties of another nat archacbacterium, which, however, grows at much lower ionic strength and which belongs to the methanogens.

\section{Materials and Methods}

\section{Siruins}

Me'humegenium! marisnigri. DSM 1498, was obtained from the Deulsche Sammlung von Mikroorganismen, Göttingen.

\section{Culturc Conditions.}

The isolate M3 was cultivalted by using the technique described by Balch and Wolfe (1976). If not mentioned "Herwise, the isolate wals grown in "M( 7 " medium, that is medium of Balch et al. (1970), modilied by the use of

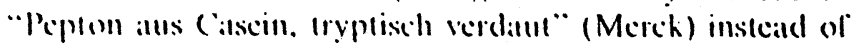

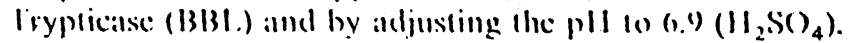

Twenty milliliter cullures were grown in stoppered pressuriged fo() ml serum hollles (Bormioli. Maly) made of "lype lll"-glass by incubaltion in waller ballh shatkers (New Brunswick) an 14(1) rpon and .37 (")

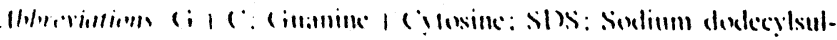
linle (Sinlumm l:unyl sullitlc)
Methanogenium marisnigri, as a reference, was grown in the same medium.

\section{Plating}

Polysilicate plates were prepared as described (Stetter et al. 1981) except that they were equilibrated with MG-medium containing penicillin, vancomycin, kanamycin (each $150 \mu \mathrm{g} / \mathrm{ml})$ and tetracycline $(100 \mu \mathrm{g} / \mathrm{ml})$ to prevent eubacterial contaminations.

\section{Light Microscopy}

The cells were viewed and photographed with a Leitz. Ortholux II microscope, equipped with a vario-orthomalt camera system (Leitz). Fluorescence was observed in a 7.eiss Standard fluorescence microscope with an excitation lilter H 436 and a selection filter LP 470.

\section{Electron Microscopy}

For thin sectioning, cell sediments were fixed in MG-medium. not containing organic components with $20 \mathrm{~g}$ glutaraldehyde/l for $2 \mathrm{~h}$ and postrixed with $10 \mathrm{~g}\left(\mathrm{OsO}_{4} / \mathrm{l}\right.$ for I h. Durcupan (Fluka) epoxy resin was used for cmbedding and thin sections were contrasted with lead citrate $(5 \mathrm{~min})$, uranylacetate $(5 \mathrm{~min})$ and again with lead citrale $(3 \mathrm{~min})$.

For shadowing, the cells were fixed on parlodion conted grids and shadowcasted (Edwards valcuum coatcr 306) with a platinum-iridium alloy (angle $7^{\circ}$ ) for $15 \mathrm{~s}$ followed by carbon coating of the parlodion film lor stabilization.

Electron micrographs were taken with a JEOL JEM $100 \mathrm{C}$ electron microscope at $80 \mathrm{kV}$ and with a $40 \mu \mathrm{m}$ objective aperture.

\section{Isolation of DNA}

Two grams cells (wel weight) were suspended in $8 \mathrm{ml}$ bulfer (50 mM Tris-HCl, pH 8: $50 \mathrm{mM} \mathrm{NaCl;} 10 \mathrm{mM}$ EIDTA). Then, SISS and Nateleoxycholate were added un to linal concentrations of (0.5\% and $7 \mathrm{mM}$. respectively. This mix/ure wals incuballed for $15 \mathrm{~min}$ al $65^{\circ} \mathrm{C}$. Then, $K(1$ was adeled lo a linal concentration of $(0.5 \mathrm{M}$. Alter I h all 2 " C the precipitated potassium laturyl sulliale was removed by centrifugaltion (20 mill, 21,000) rpm, rotor $3 \wedge 21$, Bcekman J2-21). In the next step solid CsCl $(0.92 \mathrm{~g} / \mathrm{ml})$ and ethidium bromide $(20 \mu \mathrm{g} / \mathrm{ml})$ were added to the supernatiml and centrifuged $48 \mathrm{~h}$ all 45,000 rpm (rotor 50 Ti, 20" (. Beckman L5-50). The DNAband wals isolated by suction with a syringe, cthidium 
bromide was removed by extraction $3 \times$ with $n$-butanol and the solution was dialysed against $0.1 \times \operatorname{SSC}(0.015 \mathrm{M} \mathrm{NaCl}$; $0.0015 \mathrm{M} \mathrm{Na}_{3}$-citrate).

\section{Analysis of the Cell Wall}

The existence of rigid cell wall sacculi was checked for as described by Stetter et al. (1981). Hydrolysates of whole cells were analysed for muramic acid with an amino acid analyzer (König and Stetter 1982, in preparation).

For the identification of proteins and glycoproteins, cell envelopes were obtained after sonification (Sonifier B 12, Branson Sonic Power Company) of the cells at $50 \mathrm{~W}$ for $20 \mathrm{~s}$. The lysate was suspended in basal salt medium (MGmedium without organic components), containing $1 \mathrm{mg}$ Deoxribonuclease I (Boehringer, Mannheim)/l, and was afterwards centrifuged at $40,000 \mathrm{rpm}$ (rotor $50 \mathrm{Ti}, 20^{\circ} \mathrm{C}$, Beckman L5-50). The pellet was washed twice with basal salt solution, solubilized in Laemmli's sample buffer (Laemmli 1970) and applied onto exponential polyacrylamide gels, which were prepared according to Laemmli (1970) and Mirault and Scherrer (1971). The gradient ranged from 5 to $25 \%$ polyacrylamide. The volume of the closed mixing vessel was $18 \mathrm{ml}$ for a $20 \mathrm{ml}$ gel. The gel was stained for protcin and carbohydrates with coomassic bluc and periodate-Schiffreagent (Segrest and Jackson 1972).

\section{Temperature Measurement}

Temperature in the field was determined with an electronic thermometer (Metratherm 1200d, BBC Metrawatt, Germany) equipped with elcctrode T 126.

\section{Methame Detection}

Methane wats quantitated by gas chromatography using a Hewlett Packard gas chromatograph, model $5880 \AA$ A. It was determined on a 6 feet glass column filled with Carbosieve $S$ (Supclco) at 70" C isothermal.

\section{Results}

\section{Collection of the Sample}

The sample MII/3 was taken from a small swamp composed of drilling waste, which was left from drilling the neighbouring steam well "Mofete II" near Baia in the Naples area (ltaly). The swamp is provided with water by a streamlet howing out from the condensor of the well.

Within the swamp, there were some places, were gas bubbles ascended continuously to the surface. From one of them, about $3 \mathrm{~m}$ away from the embankment, a sample $(\mathrm{MIl} / 3)$ of the loose greyish mud sediment was drawn in a depth of about $0.2 \mathrm{~m}$ with a 11 beaker mounted on a long stick. The original temperature of the sample was $19^{\prime \prime} \mathrm{C}$, the pH wass 7.0 and the conductivily was $5 \mathrm{mS}$, that is about $70 \%$ of sea water. The sample was immediatcly lilled into a sterile $100 \mathrm{ml}$ storage botlle, which was scaled with a rubber stopper aller the addition of $0.1 \mathrm{ml}$ of resilaurin (0.1\% $\mathrm{w} / \mathrm{v}$ in watcr). Then. in order 10 lower the redox potential. $1 \mathrm{ml}$ of an acueous solution of each $1.2 \%(w / v)$ of 1.-cystcin $\cdot \mathrm{HCl} \cdot \mathrm{H}_{2} \mathrm{O}$ and $\mathrm{Nal}_{2} \mathrm{~S} \cdot 9 \mathrm{H}_{2} \mathrm{O}$ (pll 7.0), adjusted with $\mathrm{NaO}() \mathrm{H}$ ) and $1 \mathrm{ml}$ of a freshly prepared aquecous solution of sodium dithionite $(0.2 \%$ $\mathrm{w} / \mathrm{v}$ ) were injected into the sample through the stopper with
$1 \mathrm{ml}$ syringes. The sample was then carried to the laboratory at room temperature (around 20" C).

\section{Enrichment}

In a Freter type anacrobic chamber (Aranki and Freter 1972), $100 \mathrm{ml}$ serum bottles containing $20 \mathrm{ml} \mathrm{MG}$-medium and $10 \mu \mathrm{g}$ vancomycin/ml were inoculated with $1 \mathrm{ml}$ of sample $\mathrm{MII} / 3$. After scaling with stoppers the serum bottles were pressurized $\left(200 \mathrm{kPa} \mathrm{H}{ }_{2}: \mathrm{CO}_{2}=80: 20\right.$; Balch and Wolfe 1976) and then incubated in a water bath shaker (New Brunswick) al $30^{\circ} \mathrm{C}$. After 3 days, low but significant amounts of methane could be detected in the gas atmosphere of the culture vessels. In the UV-fluorescence microscope, some emerald green fluorescing almost crystal-plate shaped particles were obscrved among large amounts of rods, spirilli, and, due to vancomycin, atypical spheres. A strong enrichment of this novel methanogen, designated $M 3$, was oblained by the simultancous addition of vancomycin, penicillin, kanamycin (each $150 \mu \mathrm{g} / \mathrm{ml})$ and tetracycline $(100 \mu \mathrm{g} / \mathrm{ml})$ into the $\mathrm{MG}$ medium.

\section{Isolation Procedure}

The enriched methanogen M3 could be isolated by serial dilutions in MG-medium in serum bottles. At the $10^{-x} \mathrm{di}$ lution, no infection could be detected in the microseope cven without antibiotics. To obtain single colonies, the culture was streaked parallelly onto polysilicate and onto agar plates, both prepared with MG-medium. After 3 months incubation at $30^{\prime \prime} \mathrm{C}$, round, smooth, bright ochre-colored colonics about $2 \mathrm{~mm}$ in diameter became visible on the polysilicale plales. No growth occurred on agar. From single colonics liquid cultures could be obtained over night.

\section{Culture and Storage}

Liquid cultures are routinely transferred after $2-3$ days into fresh medium (5\% inoculation). In order to preserve the strain for longer periods, it was grown for 2 days and then, after renewing the gas atmosphere, it was simply frozen and stored at $-20^{\prime \prime} \mathrm{C}$.

\section{Optimal Growth Temperature}

The isolate M 3 grows between $17^{\circ} \mathrm{C}$ and $41^{\prime \prime} \mathrm{C}$ (Fig. 1 ) with an optimum around $40^{\prime \prime} \mathrm{C}$. At $43^{\prime \prime} \mathrm{C}$ and at $15^{\prime \prime} \mathrm{C}$ no growth occurs.

\section{Growth Requireme'nts}

$\mathrm{H}_{2}$ and formate scrve as substrates for growth. In addition, acetate is essentially required (Table 1 ). $0.1 \%$ acctate is sufficient (data not shown). Optimal growth is oblained by combination of acetate with yeast extract or with peptone and vitamins (Table 1). No growth occurs on acetate alone. methanol and methylamines (data not shown) as substrales.

M.3 grows in the prescence oll (1).4 5.4 ". Nalc I(ligh. 2). The optimal sall concentraltion is aroumd I". " Nal 'I. The oplimill pll lor growlh is belween pll $6.5 \cdot 7.5$.

\section{Merphology}

In the light microscope, slowly wobbling plates wilh sharp crystal-like edges $1-3 \mu \mathrm{m}$ long and $1-2 \mu \mathrm{m}$ wide call be secn 


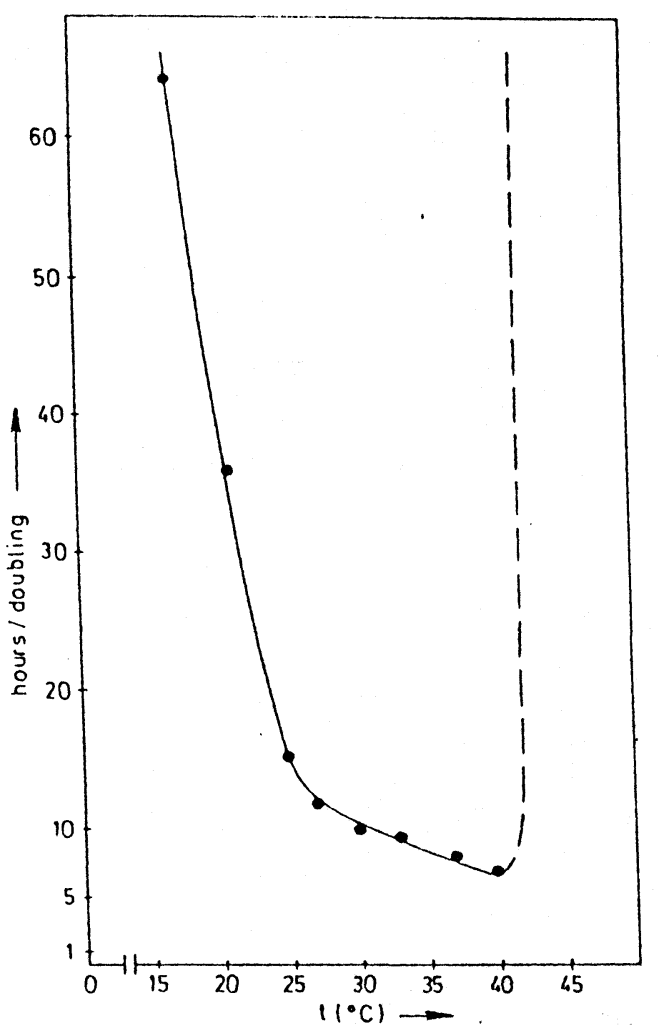

Fig. 1. Optimal growth temperature. Growth was determined several limes during the exponential phase by O.D.578-measurement. The hours/doubling were calculated firom the slopes of the growth curves (not shown)

Table 1. Influence of organic components on growth. The basal salt medium (medium 3 of Balch ct al. 1979, but without organic ingredients) was supplemented with organic components in the following concentrations: Acetate $0.1 \%$, ; peptone $0.2 \%$; yeast extract $0.2 \%$; vitamins (lrace vilamins according lo Balch cl al. 1979) $0.2 \mathrm{ml} / 20 \mathrm{ml}$ medium. Gas phase: $\mathrm{H}_{2} / \mathrm{CO}_{2}$. The samples $(20 \mathrm{ml})$ were inoculated with $1 \mathrm{ml}$ of a culture grown in a modified MG-medium, in which all organic components were reduced to $1 / 10$ of the normal concentration. The initial ().D. $57 \times$ was around $0 .(1) 3$

\begin{tabular}{|c|c|}
\hline Orgallic components & $\begin{array}{l}\text { Maximal } \\
\text { absorbance } \\
(O . D .578)\end{array}$ \\
\hline$-($ Control) & - \\
\hline Peptonc & - \\
\hline Yeast extract & - \\
\hline Vitamins & - \\
\hline Acetiatc & 0.21 \\
\hline Peptone + yeast extract & - \\
\hline Peptone + vitamins & - \\
\hline Yeist extract + vitamins & - \\
\hline Acetate + yeast extract & 0.62 \\
\hline Acetalle + peptone & 0.45 \\
\hline Acelatc + vitamins & 0.18 \\
\hline Peptone + yeast cxtract + vilanmins & - \\
\hline Acctalle I yeast extract + peptone & 0.37 \\
\hline Acclitle \& peptone + vilamins & 0.60 \\
\hline Acclatle \& vitamins + yeast extract & 0.49 \\
\hline Acetalic + yealst extract + peptone + vitamins & 0.47 \\
\hline
\end{tabular}

(lifi. 3:1). In the prolile (sece arrows). Hey appear as rods aboul $0.20 .31 \mathrm{~m}$ in diameler. The eells showed a negative gram reaction. In the electron microscope angular plates 1.6 $2.8 \mu m$ long and $1.5 \mu \mathrm{m}$ wide are visible (Figs. 3b, 4b),

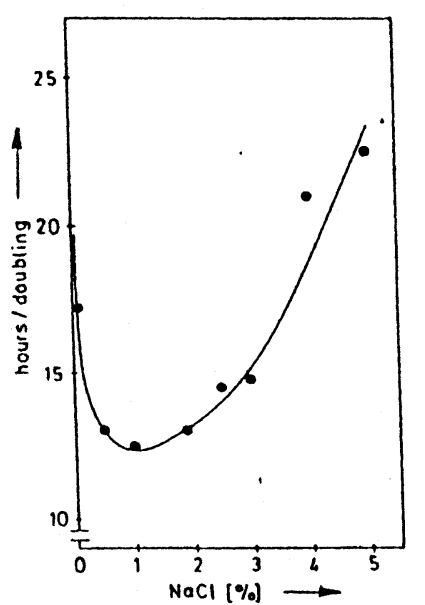

Fig. 2. Efrect of $\mathrm{NaCl}$ on growth. The $\mathrm{NaCl}$ was added to a $\mathrm{MG}$-medium prepared without $\mathrm{NaCl}$ supplement. This basal medium already contains $0.33 \% \mathrm{NaCl}$, which are not considered in the diagram

showing large indentations in the center (Fig. 3b). In crosssections, often "bone-shaped" (Fig. 3c) profiles with a diameter of only $0.07 \mu \mathrm{m}$ in the center, and $0.1-0.25 \mu \mathrm{m}$ on the ends are seen besides normal rod-shaped profiles. Sometimes also $y$-shaped cross-sections (Fig. 3e) and proffles with convexities, possibly buds, can be detected. Septa or diaphragmlike indentations were never secn. The cells often contain electron dense round inclusions, possibly granules of reserve material (Figs. 3b, 3d, 4b). In thin sections the granules frequently seem to be shrunken (Fig. $3 \mathrm{~d}$ ) or often to be broken out, leaving behind a less electron dense hole (Fig. 3c, 3d).

A polar tuft of nagella can be observed (Fig. 4a). lack nagellum is about $13.3 \mathrm{~nm}$ in diameter and up to $32 \mu \mathrm{m}$ long (not shown).

\section{Coll Envelope}

The cell envelope shows a hexagonal surface pattern (Fig. 4a). The distance of the subunits - center 10 center - was determined from EM-photographs to be $14.0 \mathrm{~nm}$. Preparations of the cell envelope show onc dominating protein band (Fig. 5, lane 3) with an appatrent molccular weight of 143,000 as determined by co-electrophoresis with molecular weight standards in the SDS-gel (Fig. 5, lane 1). This band is also stained with the periodate-Schiff-reagent (Fig. 5, lane 5), and therefore seems to be a glycoprotein. Wo believe this band to consist of the main envelope protcin. No rigid cell wall sacculi could be isolated. In accord, the cells were completely lysed with $2 \%$ SDS at room tempcraturc. No muramic acid could be detected.

\section{DNA Base Composition}

The DNA contains $47.5 \mathrm{~mol} \% \mathrm{GC}$ as determined by the melting point in $0.1 \times \operatorname{SSC}$ (Marmur and Doty 1962), using calf thymus DNA $(42 \mathrm{~mol} "$ "GC) as a reference.

\section{Discussion}

The new isolate M3 occurs as plates with sharp edges, strongly reminding of flat crystals, which in the electron microscone show an almost "pneumatic boat"-like appearence: between a surrounding puffed up roll. 0.1 $0.25 \mu \mathrm{m}$ in diameter, there is an inner plate, only 0.05 -- 

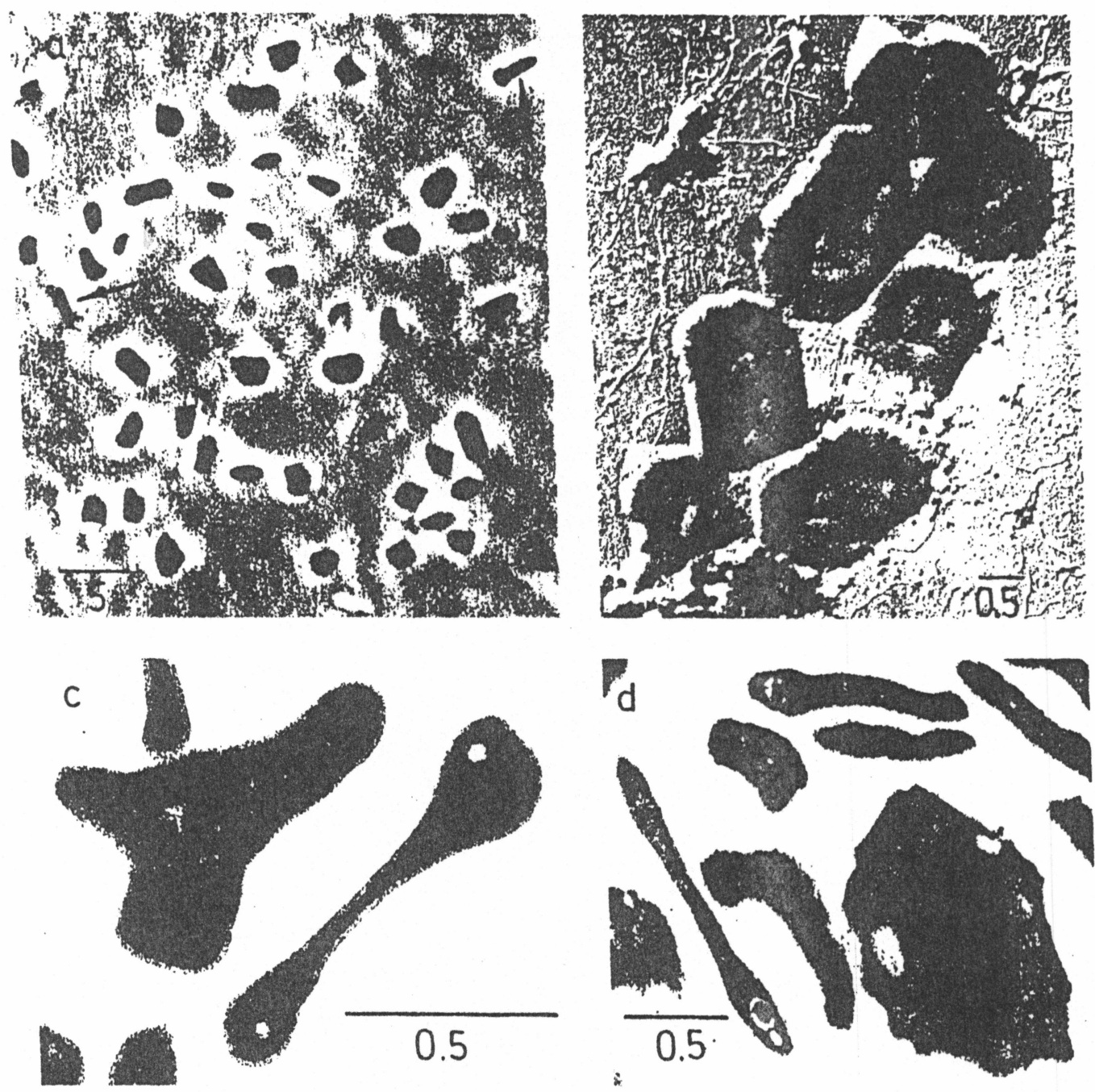

e

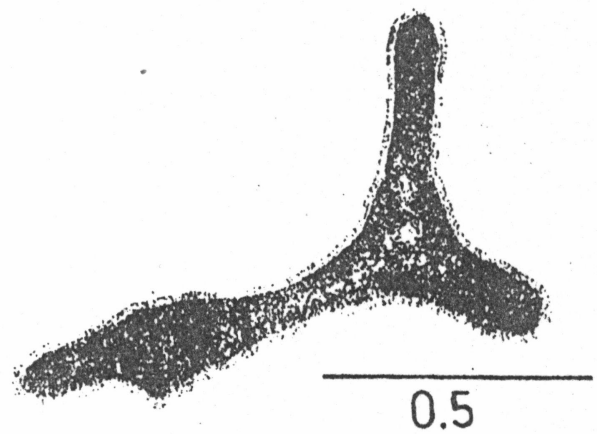

Fig. 3a-c

Light and electron micrographs of Methemephlemus limicolle. a Phatse contratst of exponentially growing cells. Arrows indicatte bacterial appearing in prolile; b platinum shadowed (7 ): c. d, e thin sections. Statements of size in $\mu$ m

$0.07 \mu \mathrm{m}$ thick, usually showing some humps. Although not qualdratic, the flat shape with the sharp edges strongly reminds of the square halophilic bacterium discovered by Walsby (1980). The novel methanogen, however, grows at much lower ionic strength. liven after a transfer in destilled waller, its llat shape is perlectly stable all leatst for hours (data notshown). The shape-maintaining principle remains unclear al the moment. ()ne could speculate, hall the organism may cillee posicss all ellicient osmoregulation or, more likely, contilin internal structures supporting the envelope in order (1) obtain the hatt shape.

No septal formation could be detected, indicalting that cell division does not occur by the usual binary lission. The $y$ - shaped profiles and the profiles with swellings in thin sections point to an unusual budding mechanism.

From its ability to form methane from $\mathrm{H}_{2}$ and $\left.\mathrm{CO}\right)_{2}$ and from its green fluoresence the new organism is clearly delined to be a methanogen. The obligate requirement' for acelale in the medium, which, however, by itself cammot serve als a substrale, wals already reported for Mte/homengenium cariaci (Romesser et al. 1979). () (her organic compounds, stech as a mixture of peptone and vitamins or yeast extract are not essential, but stimulate growilh. No methanol or melhylamines can be used, indicating that this bacterium does not belong to the Methanosarcinaceac. This is proven in addition by the lack of a rigid cell wall, the possession of llagella and 

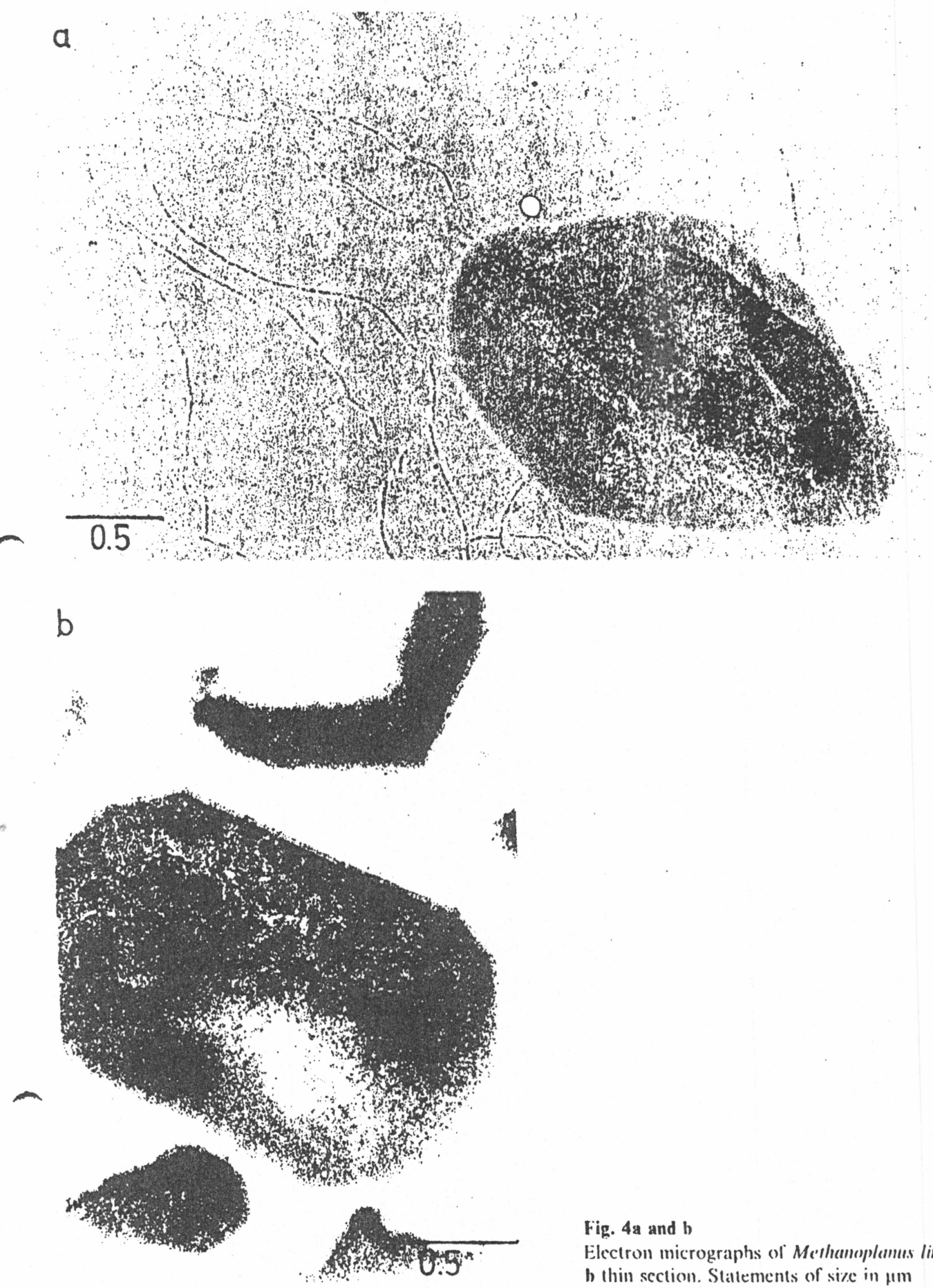

Fig. $4 \mathrm{a}$ and $\mathrm{b}$

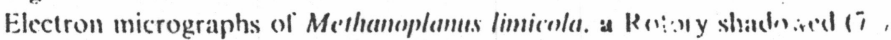
b thin section. Staltements of size in $\mu$ m

the negative gram reaction of the isolate. A close relationship to the Methanococcales, which similar to the isolate can grow on lormale. was very unlikely beciuse of a much higher GCcontent of the isolate. Due to the latter feature and based on the polyamine composition (S. Schoberth, personal communication), however, the isolate seems to belong to the Methanomicrobiales. I)NA-RNA hybridizaltion experiments (Tu et al. 1982) with DNA and ${ }^{32}$ P-labelled $16 \mathrm{~s}$ r-R.NA substantiatted this assumption: the hybrid of the M3 DNA with the Methanogenium RNA showed a higher thermostability (is = Iractional stability $=0.59$ ) than that with the Methaniocecus $\mathrm{RN} \wedge$ (fs $=0.4 .3)$, further indicating that $M .3$ belongs to the Methanomicrobiales. Winhin this or'. $\therefore$ Methanogenium RNA yielded an even more stable hyin.ji with the Methanosarcina IDNA (fs $=0.62)$, han will . vi. DNA. demonstrating that the two families are closer *: to each other than to M. Therefore, we believe tine neu isolate to be a member of at least a new family. which sis: it.11. the Methanoplanaceac.

The distribution and the biotope of the isolalle is not at a: at the moment. From its original habitat. its gerowt!, the mesophilic temperature ralnge and its salt re fuirem.nt ir.d tolerance, the organism can he assumed to has an. swamps of fieshwater and scawater. There li mas ha: 


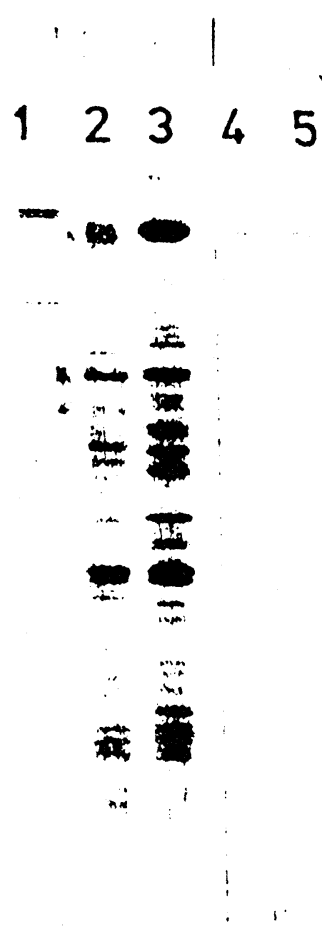

Fig. 5. SISS-polyacrylamide gel. I:lectrophoresis was performed at $110 \mathrm{~V}$ for $14 \mathrm{~h}$. (1) Molecular wcight standard: RNA polymerase subunits of Biseherichice coli (from lop to the bottom): $\left.\beta^{\prime}(160,000)\right), \beta(155,000)$, $\sigma$ (92, (1001), $\alpha(37,(000))$ : (2) and (4) envelope preparation of Merhanogenium merismigri: (3) and (5) envelope preparation of Methemeplanus limicola: (1) (3): coomassie staining: (4) and (5): periodatc-Schiff staining

previously overlooked because of its transparence and its unusual shape. Due to morphology and habitat, we name the new isolate M.3 Methamoplames limicola.

\section{Description and Classification of the Meihanoplanaceac}

()rder Melhanomicrobiales, Balch and Wolle (1976).

Family I, Methanomicrobiaceac, Balch and Wolfe (1976).

Family II, Methanosarcinaceac, Balch and Wolfe(1976).

Family III, Methanoplanaceac, Wildgruber. Thomm and Stetter (fam. nov.) Methanoplanaceac, Me. tha. no. pla. na. cci ac. M. L. neut. n. Me'hemoplames type genus of the family: -ilceace ending to denote a family: M.L. $1 \mathrm{~cm}$. pl. $\mathrm{n}$. Methanoplanaceac the Methamoplemes. lamily. The Methanoplanaceac belong to the order Methanomicrobiales, Balch and Wolfe (1976). The family Methanoplanaccac contiains one genus.

(iram-negative cells, occurring as thin plates with sharp edges. The cell envelope shows a hexagonal surface pattern. (cils oxidize $\mathrm{H}_{2}$ or formale as the sole energy source for growilh and methane production.

(jenus I Me'themoplamms, Wildgruber, Thomm and Stetter (gen. nov.) Me. that. no. plit nus. M. L. n. methamm methane; M.L. aldj. plamus flat: M. L. misc. n. Methamop/amus the methanc (-producing) plate. The description of the genus is the same as that of the lamily. Me'lhemoplamms limionla,

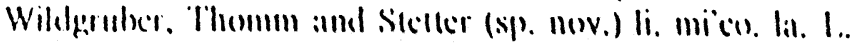

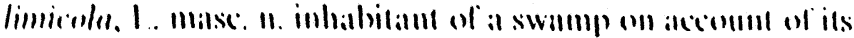
hallit:11.

Angular. erystal-like plitles 0.07 - 0.30 fum llick and 1.0$2.511 m$ lone and $1.5 \mu m$ wide, occurring singly. The colls are sometimes branched, without septa. The cell envelone shows a hexagonal surface pattern and contains a dominating glycoprotein. No sacculus is present. A polar tuft of nagella can be seen, each flagellum about $13.3 \mathrm{~nm}$ in diameter and up to $32 \mu \mathrm{m}$ long. The cells contain electron dense round inclusions, about $0.1-0.2 \mu \mathrm{m}$ in diameter. On polysilicate plates round, smooth, bright, ochrecolored, nat colonics, about $2 \mathrm{~mm}$ in diameter are formed. Weakly motile. Anacrobic. Gram-negative. Growth between $17^{\prime \prime} \mathrm{C}$ and $41^{\prime \prime} \mathrm{C}$, optimum $40^{\circ} \mathrm{C}$. Optimal salt concentration is $1 \% \mathrm{NaCl}$, optimal $\mathrm{pH}$ is $7 . \mathrm{H}_{2}$ and formate serve as substrates for growth and methane production. In addition, acctate is strictly required. No growth occurs on acetate alone, on methanol, and on methylamines. Cells are resistent against vancomycin, penicillin, kanamycin, and tetracycline.

The DNA forms complexes with $16 \mathrm{~s}$ rRNA from Methanogenium marisnigri with a fractional stability of 0.59 .

The $\mathrm{G}+\mathrm{C}$ content of the DNA is $47.5 \mathrm{~mol}$.:.

Lives possibly in seawater and freshwater swamps.

Type strain: DSM 2279.

Acknowledyements. We wish to thank Gesa Thies and Davorin lanecovic for highly valuable hints in electron microscopy. Furthermore, thanks are due to Petra Frischeisen and Lisal Kleemeier for excellemt lechnical assistence. This work was supported by a gralll from the Deutsche Forschungsgemeinschaft to K. (). Stetler.

\section{References}

Aranki $\wedge$. Freter $R$ (1972) Use of anacrobic glöve boxes for cultivaltion of striclly anacrobic bacteria. Am J (lin Nulr 25:1,324) - 13.34

Balch WI:, Fox GE, Magrum LI, Woese ('R, Wollie R.S (1979)) Methanogens: Recvaluation of a unique biological group. Microbiol $\operatorname{Rev} 43: 260-296$

Balch WE: Wolfe RS (1976) New approach to the cultivation of methanogenic bacteria: 2-mercaptoethansulfonic acid (IIS-COM)dependent growth of Methanoluacterium rumimaminum in " pressurized almosphere. Appl 'inviron Microbiol 32:781 - .701

Lacmmli I KK (1970) Cleavage of structural proteins during the assembly of the head of bacteriophange $T_{4}$. Nalture 227:680) -685

Miraull ML: Scherrer K (1971) Isolation of preribusomes from llels ceills and their charactetization by electrophoresis on uniform and exponential-gridlicnt-polyacrylamide gels. Liur J Biex-hem 2.3:372.386

Marnur 1. Doty P (1962) Delerminalion of the base compessition of decoxyribonucleic acid from its thermal denalturation temperature. J Mol Biol 5:109-118

Romesser IA. Wolfe RS. Mayer IF. Spiess I:. Wallher-Manuruschal A (1979) Methanoge'nium. a new genus of marine methannogenic bacteriat. and characterization of Melhenengentum! cariaci sp. nov. and Mcthanogenium marisnigri sp. nov. Arch Microhiol 121:147 153

Segrest IP. Jackson RL (1972) Molecular weight determination of glycoproteins by polyacrylamide gel clectrophoresis in sexlium dodecyl sulfate. In: V (jinsburg (ed) Methods in enrymology, Vol XXVIII. Academic Press, New York Londen, pp $54 \ldots 6.3$

Stetter KO. Thomm M. Winter J. Wildgruber (j, Huber II, Zillig W, Janecovic D, König H, Palm P. Wunderl S (1981) Mc'/humethin'rmmes fervides, sp. nov., a novel extremely thermophilic methanogen isolated from an leclandic loot spring. \%hl Bakt llyg. I Abl (Orig ( 2:160. 178

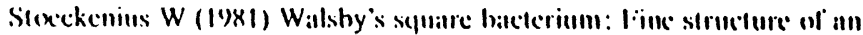

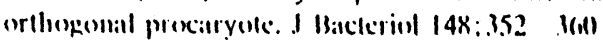

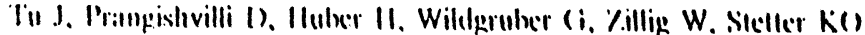

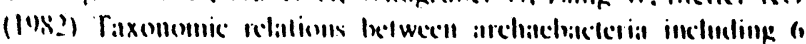

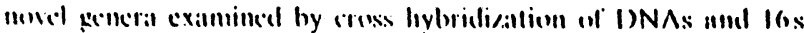
rRNA. I Mol livol (in press)

Walshy Al: (1980) $\wedge$ squalre backerium. Nalture 28.3:(1) . 71

Received liebruary 15. 1982/Accepled March 31. 19\$2 